\title{
Evaluation of Community Livelihood and Natural Resource Management - A Case in Largest Riverine Island of the World (Majuli), Assam-India
}

\author{
Niranjan Das \\ Department of Business Administration, Tezpur University, Napaam, Sonitpur-Assam, India
}

Email address:

das_niranjan2002@yahoo.com

\section{To cite this article:}

Niranjan Das. Evaluation of Community Livelihood and Natural Resource Management - A Case in Largest Riverine Island of the World (Majuli), Assam-India. American Journal of Environmental Protection. Vol. 10, No. 1, 2021, pp. 22-29. doi: 10.11648/j.ajep.20211001.13

Received: December 7, 2020; Accepted: December 15, 2020; Published: March 13, 2021

\begin{abstract}
Community-based initiatives as a potential win-win solution for improving conservation and livelihood outcomes of the riverine community. Land, forests, water bodies, orchards around homestead of families form some of the basic resources at the household level through which a family can sustain their livelihood. However, close access to the river, may provide opportunity for fishing activities and allied activities. The affinity of the community to the river and water, especially suited them with a variety of opportunistic occupations based on rather complex ecology that the Island provided, but also required the community to develop special skills and strategies to deal with a vigorous and unpredictable river and the fragile ecosystem built in the Island. Floods and erosions were not new, but are to be dealt with year after year. In the present paper an attempt has been made to access the nature and extent of depleting natural resources on Majuli Island due to flood and erosion by the River Brahmaputra and how the operational adaptive and coping livelihood strategies of the tribal communities are effective in dealing with the changing resource complexes and ensuring both the inter and intra generational sustainability.
\end{abstract}

Keywords: Resource Complexities, Floods and Erosion, Livelihood Strategies, Sustainability and Tribal Communities

\section{Introduction}

People need sustainable livelihood to ensure that they are able to access basic resources to ensure a decent life that is free of disease, hunger, unpleasantness, poverty, deprivation and denial of basic human rights [1]. Livelihood would, in that sense, be the sum total of both the employment portfolio of a household and what it earns in monetary terms, and what it receives as entitlements from the Government as citizens of the state [5]. Climate variability and extreme events have devastating impacts on communities. Therefore, many livelihood studies assume that intensive and innovative use of local livelihood strategies can result in enhanced livelihood opportunities and incomes for rural communities and equipped them to fight against the vagaries of nature [2]. The tribal communities such as Mishings, Deoris, Sonowal Kachari constitute some of the largest tribal groups in Assam. They belong to Indo-Mongoloid tribe settled mainly in the plains of Assam. These are the farming community in Majuli Island apart from other ethnic groups [3]. They mainly cultivate different varieties of wet-paddy and other winter crops like oil seed, pulses, gram, vegetables etc. Being a farming community on the Island they are settled mostly along the banks of Brahmaputra to the south and Subansiri to the north. But floods, river bank erosion and sand casting are posing a serious threat today to the life and livelihood of the tribal communities on the Island. This is resulting into a severe resource change on the Island.

\subsection{Study Area}

Majuli Island is one of the largest inhabited riverine Islands of the World. It is located between $26^{\circ} 45^{\prime} \mathrm{N}$ to $27^{\circ}$ $12^{\prime} \mathrm{N}$ latitude and $93^{\circ} 39^{\prime} \mathrm{E}$ to $94^{\circ} 35^{\prime} \mathrm{E}$ longitude and 84.50 meters above mean sea level. The geographic location of the Island is volatile. It had a total area of 1250 sq.km but having lost significantly to erosion and it has an area of only 421.65 sq.km now. It is surrounded by Subansiri River in the north and Brahmaputra River in the south. The Island is located at a distance of about $20 \mathrm{Kms}$ from the main Jorhat town. The total population of Majuli Island according to 2011 census is 
$1,73,400$ out of which 72,156 were the tribal community which accounted for 44 per cent of the total population [9].

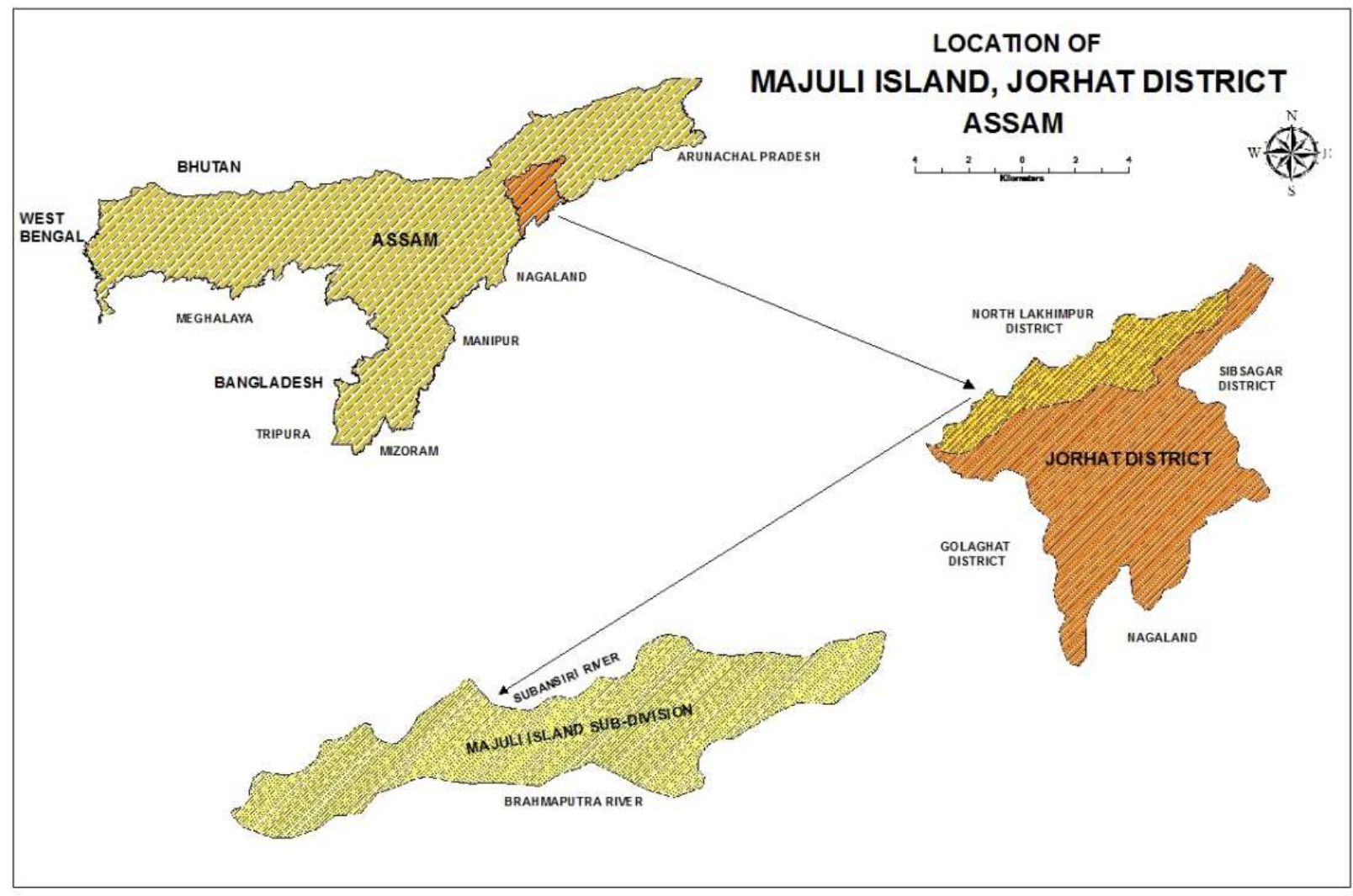

Figure 1. Location Map of Majuli Island.

\subsection{Objective}

To evaluate the livelihood strategies adopted by the tribal community in mitigating the challenges of changing resource complexities.

\section{Methodology}

The study is empirical in nature, i.e., based on the information generated from the field survey through structured interview schedules since the secondary sources of information are limited and available in some measures only. The present paper is based on the study of four tribal villages, namely 1 . No. Phutuki, 3. No. Mohkhuti, Ujoni Jokiabua and Namoni Jokiabua of Majuli Island sub-division of Jorhat District of Assam. The selection of the villages is done on random sampling basis. Combining all the four villages a total of 160 households were surveyed. Purposive random sampling technique is used for household level survey.

Detailed information is collected on a set of comprehensive interview schedules consisting of items with fixed answer categories. In formulating the schedule, an effort is made to include all those questions (with appropriate coding) which would get responses from the people. The households' interviews were seldom pre-arranged and focused. The interviews are carried on with the help of local interpreters, in a natural conversational style. Simple statistical methods for tabulation and analyses are used.

\section{Results and Discussions}

The living of man in all societies is guided by the availability of natural resources. However, the tribal communities like the Mishings, Deoris, Sonowal Kachari of Majuli who are still regarded as in the primitive stage with slow pace of development have a high degree of dependency on natural resources for their livelihoods. Land, water, forest etc., are important natural resources found on the Island and forms an integral part of their economy [12]. Let us look into the three main important natural resource of the Island around which the local livelihood system revolves.

\subsection{Natural Resources of Majuli Island}

\subsubsection{Land}

Table 1. Distribution of Land Holding Structure (in Bigha) in Majuli Island.

\begin{tabular}{lll}
\hline Total Land Holding Structure (in Bigha) & No. of HH & Percent \\
\hline$<5$ & 50 & 31.25 \\
$5-10$ & 65 & 40.63 \\
$11-15$ & 24 & 15.00 \\
$16-20$ & 9 & 5.63 \\
$21-25$ & 6 & 3.75 \\
$>25$ & 6 & 3.75 \\
Total & 160 & 100 \\
\hline
\end{tabular}

Source: Field Survey, 2015 
Table 2. Distributions of Land Holdings under Different Agricultural Categories in Majuli Island.

\begin{tabular}{|c|c|c|c|c|c|c|c|c|}
\hline \multirow{3}{*}{$\begin{array}{l}\text { Total Land } \\
\text { Holding Structure } \\
\text { (in Bigha) }\end{array}$} & \multicolumn{8}{|c|}{ Land Holding Categories } \\
\hline & \multicolumn{2}{|c|}{ Home stead } & \multicolumn{2}{|l|}{ Wet Paddy } & \multicolumn{2}{|l|}{ Ponds } & \multicolumn{2}{|l|}{ Orchards } \\
\hline & No. of HH & $\%$ & No. of HH & $\%$ & No. of HH & $\%$ & No. of HH & $\%$ \\
\hline No Land & 0 & 0 & 2 & 1.25 & 127 & 79.37 & 114 & 71.25 \\
\hline$<1$ & 57 & 35.63 & 2 & 1.25 & 10 & 6.25 & 11 & 6.875 \\
\hline $1-5$ & 102 & 63.75 & 81 & 50.63 & 23 & 14.38 & 35 & 21.87 \\
\hline $6-10$ & 1 & 0.63 & 45 & 28.13 & 0 & 0 & 0 & 0 \\
\hline $11-15$ & 0 & 0.00 & 13 & 8.13 & 0 & 0 & 0 & 0 \\
\hline$>15$ & 0 & 0.00 & 17 & 10.63 & 0 & 0 & 0 & 0 \\
\hline Total & 160 & 100 & 160 & 100 & 160 & 100 & 160 & 100 \\
\hline
\end{tabular}

Source: Field Survey, 2015

Land is an important resource and serves both as a natural resource and natural capital in providing sustainability to tribal economy on the Island [13]. Land is assessed into two categories viz; total land holding (see table 1) and land holding under different agricultural categories (see table 2). The measuring unit for all land holdings is Bigha ${ }^{1}$.

Out of the total 160 households surveyed (combining four villages) although every household is found to possess some amount of land, but the holdings are not uniform in distribution. It is observed from the table 1 that 40.63 percent of households have low land holdings of 5 to 10 bigha, followed by 31.25 percent of households having very low land holdings of less than 5 bigha. 15.00 percent of household have moderate landholdings of 11-15 bigha and 5.63 percent of household have high land holding of 16-20 bigha. Only a small 7.5 percent of household are found to possess very high landholdings of above 20 bigha.

We further assessed the importance of land as a natural capital for the tribes by dividing the holdings into four different agricultural land categories i.e., homestead, wet paddy, ponds and orchards. It is observed from table 2 that maximum number of households have their land mainly fewer than two categories i.e., homestead and wet-paddy and only a negligible percent of people have land under ponds and orchards. Even in this case also there is a lack of uniformity in terms of land possession under different categories except land under wet-paddy. Percent of holdings under Ponds and orchards is found to be quite negligible

Therefore, in terms of overall landholding structure in relation to landholdings under different categories it may be assumed from the above analysis of aforesaid table 1 and table 2 that land is an important natural resource. But in terms of size of land holdings it seems that the holdings are getting fragmented. This clearly reflects that the carrying capacity of the Island may get severely affected within few years to come.

\subsubsection{Forest}

Next to land forest resources plays an important role in governing the community livelihood of Majuli Island. They

11 Bigha in Assam =14,400 square feet (1337.8meter square) mainly serve the purpose of fuel wood and income in the form of NTFPs (Non-Timber Forest Products) for the local households of the Island.

Table 3. Fuel Wood Collections by Household (in Quintal/Month).

\begin{tabular}{lll}
\hline Quantity (in Quintal/month) & No. of HH & Percent \\
\hline No use of fuel wood & 3 & 1.88 \\
$<2$ & 37 & 23.13 \\
$2-4$ & 83 & 51.88 \\
$5-7$ & 29 & 18.13 \\
$>7$ & 8 & 5.00 \\
Total & 160 & 100 \\
\hline
\end{tabular}

Source: Field Survey 2015

Forest supplies like fuel wood and diverse NTFPs contributes greatly to the livelihood system of the community in Majuli Island. Wood is an essential commodity to meet the fuel requirement of the Household. The forests of the Island provide a good source of supply of fuel wood to the local households. 98.12 percent households are found to be dependent on the forest to meet their fuel requirement. Such over dependency of households on forests to meet their domestic fuel requirement could lead to large scale deforestation with increasing population pressure.

Table 4. Income of Household from NTFPs (Per year in Rs.).

\begin{tabular}{lll}
\hline Value in Rs. & No. Of HH & Percent \\
\hline No Income from NTFP & 29 & 18.13 \\
$500-999$ & 3 & 1.88 \\
$1000-1499$ & 25 & 15.63 \\
$1500-1999$ & 17 & 10.63 \\
$2000-2499$ & 15 & 9.38 \\
$2500-2999$ & 11 & 6.88 \\
$3000-3499$ & 26 & 16.25 \\
$3500-3999$ & 14 & 8.75 \\
$>4000$ & 20 & 12.5 \\
Total & 160 & 100 \\
\hline
\end{tabular}

Source: Field Survey, 2015

Forests have not only contributed in meeting the domestic fuel requirement of the local households but have also provided them with verities of NTFPs which supplements their main income source i.e., agriculture. It can be trace from (table 4) that a good majority of the local households 
derive some income annually through the sale of NTFPs which they collect from different forested tracts of the Island.

\subsubsection{Water}

Water as natural resource is one of the most essential resource for the communities. Being riverine communities to a large extent, their economy and livelihood depends on the availability of water resources [14]. Moreover, fishing which is their second main economic activity next to agriculture is mostly provided by the rivers, streams, ponds and beels (wetland) of the Island.

Table 5. Weekly Catch of Fish (in Kg.) By Households.

\begin{tabular}{lll}
\hline Weekly Catch of Fish (in Kg.) & No. of HH & Percent \\
\hline No. Catch of Fish & 67 & 41.88 \\
$<2$ & 16 & 10.00 \\
$2-4$ & 56 & 35.00 \\
$5-7$ & 17 & 10.63 \\
$>7$ & 4 & 2.50 \\
Total & 160 & 100 \\
\hline
\end{tabular}

Source: Field Survey, 2015

Even though fishing constitutes an important economic activity for the communities, 41.88 per cent of households stated that they do not indulge in any fishing activities. This indicates a slow decline in the fish catch. More over whatever percent of households were found to indulge in weekly catch of fish mainly utilised those catch for domestic consumption and not for commercial sale. This indicates that fishing is no longer a profitable livelihood option for a majority of households except a few well to do households with a substantial amount of land holding under ponds.

Table 6. Annual Incomes of Households from Fish Sale.

\begin{tabular}{lll}
\hline Income in Rs. & No. of HH & Percent \\
\hline No Income from fish sale & 119 & 74.38 \\
$<2000$ & 12 & 7.5 \\
$2000-2999$ & 6 & 3.75 \\
$3000-3999$ & 7 & 4.38 \\
$4000-4999$ & 2 & 1.25 \\
$>=5000$ & 14 & 8.75 \\
Total & 160 & 100 \\
\hline
\end{tabular}

Source: Field Survey, 2015

\subsection{Resource Dependency of the Community}

It is seen from table 6 that a greater percent of 74.38 per cent of households stated that they do not earn any income through fish sale annually. Whatever 25.62 per cent of household found to have some annual income from fish sale constitutes of those households who possess some land in the form of water body like pond. Among these household also only 8.75 per cent of households have some considerable amount of income annually from fish sale. Others have negligible income.

From the above discussion it may be stated that sustainable development of the tribal community in Majuli Island depends largely on renewable natural recourses of land, water, air, plants and forests. The utility or potentiality for producing goods and services, of these natural systems is to be continued to ensure both intra and inter-generational sustainability [11]. The complexities that are arising in the form of fragmentation of land holdings, over dependency on forest resources, declining fish catch and non-profitability of fishing activities poses a potential threat for the riparian communities like Mishing, Deori and Sonowal Kachari on the Island.

\section{Livelihood Strategies of Tribal Communities against Changing Resource Complexes}

\subsection{Coping Strategies}

Coping is a way of responding immediately to a hazard in order to reduce the intensity of its impact for a short time. Coping can mean the adoption of ad hoc and short-term measures by villagers to save their lives or property when they are hit by the first wave of flood or a natural disaster [4]. Coping also includes intermittent measures that are not regularly or uniformly practiced but which are effective in reducing vulnerability or enhancing resilience to various degrees [13]. Some of the coping strategies adopted by the households of Majuli Island are discussed below.

Table 7. Types of Borrowing by the Households at times of Natural Calamities.

\begin{tabular}{lll}
\hline Borrowing Types & No. of HH & Percent \\
\hline No borrowing & 26 & 16.25 \\
Money & 22 & 13.75 \\
Food Items (including grains) & 13 & 8.13 \\
HH Goods/Items & 35 & 21.88 \\
Agricultural Tools & 4 & 2.5 \\
Money and Food Items (including grains) & 29 & 18.13 \\
Money and HH Goods/Items & 8 & 5 \\
Food Items (including grains) and HH Goods/Items & 7 & 4.38 \\
Food Items (including grains) and medicines & 1 & 0.63 \\
HH Goods/Items and Medicines & 9 & 5.63 \\
HH Goods/Items and agricultural tools & 2 & 1.25 \\
Medicines and Agricultural tools & 4 & 2.5 \\
Total & 160 & 100 \\
\hline
\end{tabular}

Source: Field Survey, 2015

Borrowing is the most common and immediate form of coping strategy adopted by any rural community across the globe [8]. It is seen from the table 8 that various types of goods (both single item and combination of items) are borrowed by the households. The most common type of borrowing done by the households are household gods and items (21.88\%) money and food items (18.33\%), money (13.75\%) and food items (8.13\%). 16.25 per cent do not resort to any type of borrowings and likes to use their own assets. This group mainly comprises of those households who other than agriculture have some or the other form of fixed and regular source of income.

Table 8. Financial Strategies of Households during Natural Calamities. 


\begin{tabular}{lll}
\hline Sources & No. of HH & Percent \\
\hline $\begin{array}{l}\text { Use of personal savings } \\
\text { Borrowing from friends/relatives/neighbours } \\
\text { (with interest) }\end{array}$ & 42 & 26.25 \\
$\begin{array}{l}\text { Borrowing from friends/relatives/neighbours } \\
\text { (without interest) }\end{array}$ & 57 & 1.88 \\
Borrowing from moneylender & 12 & 35.63 \\
Loan from bank & 1 & 7.50 \\
Sell HH goods/items & 7 & 0.63 \\
Mortgage land & 3 & 4.38 \\
Others & 35 & 1.88 \\
Total & 160 & 21.88 \\
\hline
\end{tabular}

Source: Field Survey, 2015

It is found that 35.63 per cent of household's resort to borrowing from friends/relatives/ neighbours (without interest) when there is a sudden need for money. Next 26.25 per cent of households use their personal savings to meet their monetary requirements. 21.88 per cent of households have Other $^{2}$ sources of meeting their financial requirements. 7.50 per cent resort to borrowings from moneylender with exorbitant rates of interest. Therefore, it can be clearly stated from the analysis of the table 9 that 73.75 per cent of households (since $26.25 \%$ use their own personal savings) are directly dependent on some or the other source for economic help as and when the need arises. In fact, this dependency is a part of their coping strategy, which they adopt for their survival and maintenance.

Table 9. Reductions in Expenditure during Natural Calamities.

\begin{tabular}{lll}
\hline Reduce expenditure towards & No. of HH & Percent \\
\hline No reduction in expenditure & 6 & 3.75 \\
Food Consumption & 57 & 35.63 \\
Clothes and HH Items & 37 & 23.13 \\
Education of Children & 1 & 0.63 \\
Festivals and fairs & 17 & 10.63 \\
Food Consumption and clothes and HH items & 29 & 18.13 \\
Food Consumption and festivals and fairs & 5 & 3.13 \\
Clothes and HH Items and Festivals and fairs & 7 & 4.38 \\
Others & 1 & 0.63 \\
Total & 160 & 100 \\
\hline
\end{tabular}

Source: Field Survey, 2015

Reduction in expenditure or consumption level is another form of coping strategy followed by the households at times of despair. We can see from the table 10 that most of the households cut short in their consumption or expenditure level of various items and goods during hard times. It is seen that the most of the households reduces expenditure mainly towards food consumption (35.63\%) and clothes and household items $(23.13 \%)$. On the other hand, 18.13 per cent of households reduce expenditure towards both food consumption and clothes/household items. 10.63 per cent of households reduce expenditure towards fairs and festivals. Only 3.75 per cent of

2 Other sources of financial borrowings here refers to that except the aforesaid sources of borrowings as shown in table 9, some households are also found to have more than one source of borrowing which are found in different combination. Say for example some households have two sources of borrowing like borrowing from friends/relatives/neighbours (without interest) as well as sell hh goods/items. Similarly, some households use personal savings as well as take loans from bank as and when the need arises. households stated that they do not have any expenditure cut.

Table 10. Seeking of Alternate Occupation by the Households other than Farming.

\begin{tabular}{lll}
\hline Alternate employment option & No. of HH & Percent \\
\hline No source of alternate employment & 23 & 14.38 \\
In relief works & 14 & 8.75 \\
Within same locality & 90 & 56.25 \\
Migration & 17 & 10.63 \\
In relief works and within same locality & 9 & 5.63 \\
In relief works and Migration & 2 & 1.25 \\
Within same locality and Migration & 5 & 3.13 \\
Total & 160 & 100 \\
\hline
\end{tabular}

Source: Field Survey, 2015

Table 11 highlights on the alternate occupational structure (other than farming) of the households in Majuli Island. It is palpable from the table 11 that 85.62 per cent households seek some alternate occupation other than farming to support their livelihood. Only 14.38 per cent of households stated that they do not have any alternate employment option. Among those households seeking alternate employment the highest per cent of 56.25 households seek employment within the same area. 10.63 per cent migrates from Majuli to the neighbouring towns in search of better income opportunities. These migrated group normally consists of skilled and semi- skilled workers. While 8.75 per cent seek employment in the relief camps which are organised by various government and non-government agencies in Majuli at times of floods etc. While a small percent of households is also found to engage in more than one occupation. They mainly comprise of non-skilled to semi-skilled households.

\subsection{Adaptive Strategies}

Adaptation is a set of actions resorted to over a long term to reduce the adverse impacts of floods or other such adverse condition on peoples' lives. Adaptation practices evolve or are acquired over a long-time span as response to impacts of floods, erosion and other hazards which are regular in nature over the long run [10].

Overcoming, physical, natural, social and cultural barriers to cope with floods and reduced natural resources the tribal communities have started to embrace some adaptive strategies to earn their livelihoods and maintain sustainability [6]. A gist of these few adaptive structural strategies is discussed in the following paragraphs below

Table 11. Type of House in Majuli Island.

\begin{tabular}{lll}
\hline House Type & No. of HH & Percent \\
\hline Assam type (kutcha) & 8 & 5 \\
Assam type (pucca) & 10 & 6.25 \\
Traditional Chang Ghar (thatch roof) & 28 & 17.5 \\
Traditional Chang Ghar (tin roof) & 89 & 55.63 \\
Traditional chang ghar (pucca) & 7 & 4.38 \\
RCC building & 6 & 3.75 \\
Assam type (pucca) and Traditional chang ghar & 2 & 1.25 \\
(tin roof) & & \\
Traditional Chang ghar (thatch roof) and & 9 & 5.63 \\
Traditional chang ghar (tin roof) & & \\
\hline
\end{tabular}




\begin{tabular}{lll}
\hline House Type & No. of HH & Percent \\
\hline Traditional chang ghar (tin roof) and RCC Building & 1 & 0.63 \\
Total & 160 & 100 \\
\hline
\end{tabular}

Source: Field Survey, 2015

A tribal village is distinguished by typical long dwelling houses locally known as 'Chang Ghar' in Majuli and elsewhere in Assam. These houses are built on a bamboo platform raised about six feet from the ground on wooden poles. The width of a house is about 20 feet and its length depend on the size of the family that occupies it. Some of the bigger houses are almost 120 feet in length. The main strength of the house is that they are highly adapted to frequent floods that visit Majuli almost every year. This gets clearly reflected in table 12 as majority of the household are found to have traditional 'chang ghar'. Unless the flood water rises as high as seven feet, the house is quite safe. This house is a classic example of physical adaptation that has evolved through the experience of a riparian community which serves as a great strength for them during the time of natural crisis.

Table 12. Possession of Boats.

\begin{tabular}{lll}
\hline Possession of Boats & No. of HH & Percent \\
\hline No boats but use of indigenous rafts & 118 & 73.75 \\
Traditional country made boats & 40 & 25 \\
Motor Boats & 2 & 1.25 \\
Total & 160 & 100 \\
\hline
\end{tabular}

Source: Field Survey, 2015

Normally in a fragile ecosystem like Majuli, possession of a boat serves as a great adaptive strategy against any water induced calamity like flood. Generally, every household possesses a boat and if not, they are expert makers of rafts which normally they carve out of banana tree trunks as and when the need arises.

Table 13. Adoption of New Vocations other than Traditional Agricultural Activities.

\begin{tabular}{lll}
\hline Vocations & No. of HH & Percent \\
\hline No New Vocations & 34 & 21.25 \\
Government Jobs & 14 & 8.75 \\
Private Jobs & 2 & 1.25 \\
Self -employed (business) & 10 & 6.25 \\
Agricultural, fishery and forestry labourers & 44 & 27.5 \\
Labourers in mining, construction, manufacturing & 8 & 5 \\
and transport & & \\
Building and related trade workers (excluding & 15 & 9.38 \\
electricians) & & 1.88 \\
Handicrafts, garments, other crafts and related works & 3 & 6.25 \\
Refuse workers and other elementary workers & 10 & 12.5 \\
Others & 20 & 100 \\
Total & 160 & \\
\hline
\end{tabular}

Source: Field Survey, 2015

Normally in a rural economy depletion and scarcity of natural resources induce people to adopt new vocations to supplement their incomes and livelihood [9]. Table 14 reflects on this aspect in response to changing resource complex in Majuli Island. 27.5 per cent of households are found to work as daily wage labourers in agricultural, fishery and forestry sectors, 21.25 per cent do not have any new vocations and are solely dependent on farming activities. 12.5 per cent of them have other ${ }^{3}$ vocations. Overall, it is observed that even though quite a few percent households are found to have a mixed bag of occupations other than traditional agricultural activities. But when compared it is found that still a great majority of the households are still dependent on agricultural and allied activities or they do not have any other new vocations only. It is observed during the field survey that there is a great potentiality in Majuli Island for many vocations to develop on scientific and commercial line which can be a great source of income and livelihood for the tribal community, thereby, reducing their direct dependency on the natural resources.

Table 14. Adoption of Modern Crop Cultivation Techniques.

\begin{tabular}{lll}
\hline Type of modern crop cultivation & No. of HH & Percent \\
\hline No adoption of modern crop cultivation techniques & 80 & 50 \\
HYV seeds & 18 & 11.25 \\
Use of chemical fertilizers and pesticides & 21 & 13.13 \\
Use of tractors & 5 & 3.13 \\
Whole new crop & 11 & 6.88 \\
HYV seeds and use of chemical fertilizers/pesticides & 4 & 2.5 \\
HYV seeds and Irrigation & 7 & 4.38 \\
HYV seeds and whole new crop & 3 & 1.88 \\
Use of chemical fertilizers/pesticides and use of & 3 & 1.88 \\
tractors & & \\
HYV seeds, use of chemical fertilizers/pesticides & 3 & 1.88 \\
and irrigation & & 3.13 \\
Others & 5 & 100 \\
Total & 160 & \\
\hline
\end{tabular}

Source: Field Survey, 2015

Table 15 presents an interest picture of use of modern crop technique as a long-term adaptive livelihood strategy. On the one hand it is seen that 50 per cent of households in Majuli Island do not use any modern crop cultivation technique and on the other hand the remaining 50 per cent of households do have some modern crop cultivation technique cultivation in various measures and degree. Now in the light of the above table 15 let us look into some of the land management practises found in Majuli Island which will give us a better picture of the true agricultural scenario on the Island.

Table 15. Land Management Practises used by the Households.

\begin{tabular}{lll}
\hline Land Management Practices & No. of HH & Percent \\
\hline No land management practices & 33 & 20.63 \\
Intensification & 15 & 9.38 \\
Diversification of land use & 22 & 13.75 \\
Expansion of area under agriculture & 3 & 1.88 \\
Irrigation & 10 & 6.25 \\
Use of inorganic fertilizers & 9 & 5.63 \\
Application of compost manure & 3 & 1.88 \\
De-weeding/burning & 23 & 14.38 \\
Intensification and diversification of land use & 8 & 5.00 \\
\hline
\end{tabular}

3 Others here refers to a host of miscellaneous vocations/occupations performed by the households as part time of fulltime activities other than traditional agricultural activities to supplement their income sources at times of difficulties. 


\begin{tabular}{lll}
\hline Land Management Practices & No. of HH & Percent \\
\hline Intensification and Irrigation & 2 & 1.25 \\
Intensification and use of inorganic fertilizers & 2 & 1.25 \\
Intensification and de-weeding/burning & 2 & 1.25 \\
Diversification of land use and irrigation & 3 & 1.88 \\
Diversification of land use and use of inorganic & 5 & 3.13 \\
fertilizers & & 2.50 \\
Diversification of land use and de-weeding/burning & 4 & 2.50 \\
use of inorganic fertilizers and de-weeding /burning & 4 & 1.25 \\
Application of compost manure and & 2 & 6.25 \\
de-weeding/burning & 10 & 100 \\
Others & 160 & \\
Total & &
\end{tabular}

Source: Field Survey, 2015

Management of land resources has been one of the major hindrances for the rural poor of Majuli. Some amount of land management practices is found to be practised by the households. 79.37 per cent of household's practise land management, while, 20.63 per cent of households reported that they do not indulge in any land management practices. It is observed that many households adopt more than one method to maintain the quality of their land. Irrigation is considered to be the best form of land management for any agrarian economy [7]. But in Majuli Island irrigation facilities are not well developed or poorly developed. Only 6.25 per cent of households have irrigation facilities on their fields. Development of proper irrigational facilities is very necessary for the management of land resources in Majuli. Proper irrigational facilities can ensure self-sufficiency in agricultural crop production mainly wet paddy and mustard seed cultivation during the post monsoon periods which in the long run will increase the fertility of the soil leading to an increase in crop yield and ensuring sustainability of the traditional Mishings of Majuli.

\section{Conclusion}

The foregoing discussion has highlighted that livelihoods of the disadvantaged and partially resource poor communities like the Mishings, Deoris and Sonowal Kacharis of Majuli need to be targeted for improvement. Sustainable livelihood requires building on aspects of potential existing livelihood options that is available in the area. Land is found to be the most important natural resource for them, the rights of which are passed on from one generation to another generation. But today this holds no good for the future generations to come since land is become scarce day by day owing to flood, growing population pressure (leading fragmentation of land) and rapid rate of erosion. Erosion, floods and increasing population are greatly affecting the carrying capacity of the island which in turn is creating severe pressure on the already depleting land, forest, water and other natural resources of the area. The traditional coping and adaptive strategies are not strong enough in dealing with the changing nature of Majuli's ecosystem. The coping and adaptive strategies that are into operation in the traditional tribe's hearths of the island ensures livelihood and maintenance only in the short run i.e. it ensures intra-generational sustainability but do not guarantees inter- generational sustainability. So overall there is a need to assess the entire web of livelihood strategies (both coping and adaptive strategies) which are being adopted and practised by the tribes of Majuli Island. there is an urgent need of review and understanding of how the people are mitigating with floods and erosion and document their specific coping and adaptive strategies, both traditional and contemporary so that on the lines of which proper scientific measures can be taken and implemented on the island to protect and ensure the livelihood and sustainability of its inhabitants both in the short run as well as in the long run in the future.

\section{References}

[1] Appasamy, Paul P. (1993). Role of Non-Timber Forest Products In a Subsistence Economy: The Case of a Joint Forestry Project in India. Journal of Economic Botany, vol 47 (3), New York: The New York Botanical Garden Bronx. Pp. 258-267.

[2] Barret, Christopher B. (2008). Poverty and the Environment: Understanding Linkages at the Household Level, Washington D. C.: The World Bank Press. Pp. 1-24.

[3] Bhandari, J. S. (1992). Kinship, Affinity and Domestic Group: A Study among the Mishing of the Brahmaputra Valley, New Delhi: Gyan Publishing House. Pp. 23-28, 40-42 and 161-176.

[4] Das, Gurudas, (ed.) (2005). Structural Change and Strategy of Development: Resource-Industry Linkages in North East India, New Delhi: Akansha Publishing House. Pp. 135-136.

[5] Ganguly, J. B. (1996). Sustainable Human Development in the North-Eastern Region of India, New Delhi: Regency Publications. Pp. 36-37.

[6] Hazarika, Sanjay, (2006). Living Intelligently with Floods, Background Paper No. 5, New Delhi: Centre For Northeast Studies And Policy Research, Retrieved October 5, 2012 from worldbank website, www.siteresources.worldbank.org/../Resources/Background_P aper_5.pdf.

[7] ICIMOD and Aaranyak. (2009). Adjusting to Floods on the Brahmaputra Plains, Assam, India, Retrieved April 4, 2012 from aaranyak website, www.aaranyak.org

[8] Mipun, Jatin. (1993). The (Miris) of Assam, New Delhi: Gian Publishing House. Pp. 1-30, p. 32, and Pp. 38-42.

[9] Nath, D. (2009). The Majuli Island: Society, Economy and Culture, New Delhi: Anshal Publishing House. Pp. 1-24, 7793 and $120-133$.

[10] Nath, Gunaram. (2012). Human-Induced Threats To BioDiversity in North-East India with Special Reference to Majuli. International Journal for Basic Sciences and Social Sciences, Vol 1 (1) Retrieved November 4, 2012 from website www.rfbss.org/journal/index.php/usbss/article/

[11] Pande, G. C. (2003). Social Sustainability and Economic Development, New Delhi: Anamika Publishers. Pp v-ix.

[12] Rao, P. K. (2000). Sustainable Development: Economics and Policy, Massachusetts: Blackwell Publishers. Pp. 33-42, 8788, 113-125 and 241-242. 
[13] Redclift, Michael. (ed.) (2000). Sustainability: Life Chances and Livelihoods, New York: Routledge Publications. Pp. 1-12 and 17-32.
[14] Titus, Milan J. and Burgers, Paul P. M. (ed.) (2008). Rural Livelihoods, Resources and Coping with Crisis In Indonesia: A Comparative Study, Amsterdam: University Press. 